\title{
Short-Term and Long-Term Inhibitory Effects of Copper on Anammox Process ${ }^{\dagger}$
}

\author{
Cigdem Kalkan Aktan 1,*, Ayse Ekin Uzunhasanoglu ${ }^{1}$, Kozet Yapsakli ${ }^{1}$ and Bulent Mertoglu ${ }^{2}$ \\ 1 Department of Environmental Engineering, Faculty of Engineering, Marmara University, Goztepe, \\ Istanbul 34722, Turkey; ekin.uzunhasanoglu@gmail.com (A.E.U.); kyapsakli@marmara.edu.tr (K.Y.) \\ 2 Department of Bioengineering, Marmara University, Goztepe, Istanbul 34722, Turkey; \\ bulent.mertoglu@marmara.edu.tr \\ * Correspondence: cigdemkalkan@marmara.edu.tr; Tel.: +90-533-724-06-10 \\ + Presented at the 3rd EWaS International Conference on "Insights on the Water-Energy-Food Nexus", \\ Lefkada Island, Greece, 27-30 June 2018.
}

Published: 30 July 2018

\begin{abstract}
The main goal of this study is to evaluate the short-term and long-term inhibitory effects of $\mathrm{Cu}$ (II) on Anammox process. To investigate the short-term inhibition level, four different concentrations $\left(1,2.5,5\right.$ and $10 \mathrm{mg} \mathrm{L}^{-1}$ as $\left.\mathrm{Cu}^{2+}\right)$ were tested in batch reactors. IC50 levels for short-term exposure deduced as $4.57 \mathrm{mg} \mathrm{L}^{-1}\left(\mathrm{R}^{2}: 0.97\right)$ from the modified non-competitive inhibition model. Lab-scale continuous flow up-flow fixed bed reactor with Kaldness biofilm carriers was operated 240 days with gradually increased $\mathrm{Cu}$ concentrations (from 0.2 to $8 \mathrm{mg} \mathrm{L}^{-1}$ ). To identify the IC50 levels in case of prolonged exposure of $\mathrm{Cu}(\mathrm{II})$, experimental data were fitted with a modified non-competitive inhibition model, and calculated as $6.77 \mathrm{mg} \mathrm{L}^{-1}\left(\mathrm{R}^{2}: 0.95\right)$. The results show that the IC50 level for copper in long-term exposure was higher than in short-term exposure and the possible reason for that is the self-adaptation of Anammox bacteria.
\end{abstract}

Keywords: anammox; copper; inhibition; nitrogen removal; heavy metal

\section{Introduction}

Nitrogen is the most common and important problem in industrial and domestic wastewater streams [1]. Therefore, there is an emerging concern to develop new technologies to get rid of nitrogen compounds [2]. For the past twenty-five years, there has been a rapid rise in the field of research about Anaerobic Ammonium Oxidation (Anammox) process which has a crucial potential to treat high nitrogen loaded wastewater streams. In the anammox process ammonium is oxidized to dinitrogen gas in anoxic conditions with hydrazine as an intermediate [3]. The Anammox process is found as promising alternative and cost-effective because of low aeration requirements and less sludge production comparing to conventional nitrogen removal process [4,5]. Due to the low growth rate with a doubling time 11 days (at $\mathrm{pH} \mathrm{8)} \mathrm{[6]} \mathrm{of} \mathrm{anammox} \mathrm{bacteria} \mathrm{efficient} \mathrm{biomass} \mathrm{retention} \mathrm{is}$ needed for the cultivation and enrichment period [7]. In order to provide high biomass concentration in the reactor systems, some solid support materials like non-woven biomass carriers $[8,9]$, Kaldnes rings $[10,11]$ or glass beads [12] were used in the literature.

Anammox process is applicable for especially ammonium-rich wastewaters such as landfill leachates $[13,14]$, anaerobic digester rejects water $[15,16]$, wastewater from semiconductor factories [17] and sludge liquors [18]. However, this process has been restricted by environmental and operational conditions due to vulnerable structure and slow growth rate of Anammox microorganisms [4,19]. Consequently, many studies have been focused on a great variety of inhibitory factors over the Anammox process in wastewater streams including organic matter [20], substrates [11,21,22], salts [23] etc. So far, however, little attention has been paid to inhibitory effects 
of heavy metals [24-28] and little is known about the short and long-term effect of copper on Anammox activity.

Ammonium-rich wastewater streams such as landfill leachates may contain heavy metals at high concentration like; cadmium $\left(\mathrm{Cd}^{2+}\right)$, chromium $\left(\mathrm{Cr}^{3+}\right)$, copper $\left(\mathrm{Cu}^{2+}\right)$, lead $\left(\mathrm{Pb}^{2+}\right)$, nickel $\left(\mathrm{Ni}^{2+}\right)$, and zinc $\left(\mathrm{Zn}^{2+}\right)$ [29]. Although some of the heavy metals are fundamental for microbial cell production, they are also common inhibitors for biological processes in high concentrations. Although some specific heavy metals have been studied $\mathrm{Cd}(\mathrm{II}), \mathrm{Cu}(\mathrm{II}), \mathrm{Ni}(\mathrm{II}), \mathrm{Zn}(\mathrm{II}), \mathrm{Hg}, \mathrm{Pb}, \mathrm{Ag}$ on Anammox activity [24-28,30-34], there has been little agreement on inhibition doses of these heavy metals. However, the experimental data are rather controversial, and there is no general agreement about inhibitory concentrations. A number of studies have examined the short-term inhibition level of $\mathrm{Cu}(\mathrm{II})$ on Anammox activity. Even though there were some studies published about the short-term effects of $\mathrm{Cu}(\mathrm{II})$, little is known about the long-term response of $\mathrm{Cu}$ (II) on the Anammox process [26,30]. Consequently, it is necessary to evaluate the inhibition level of $\mathrm{Cu}$ on the Anammox process for both short and long-term exposure, and further studies should be carried out.

Therefore, the present paper aims to analyze the short and long-term effects of $\mathrm{Cu}$ on the Anammox system. In order to determine the short-term effect of $\mathrm{Cu}$ batch tests were conducted for $24 \mathrm{~h}$. Lab-scale continuous flow up-flow fixed bed reactor was operated to investigate the effect of prolonged exposure of $\mathrm{Cu}$ on the Anammox process.

\section{Material and Methods}

\subsection{Anammox Seed Sludge and Synthetic Wastewater}

The seed sludge was taken from ongoing lab-scale up-flow column reactor that enriched over six years. Reactors inoculated with Anammox culture containing approximately $1000 \mathrm{mg} \mathrm{L}^{-1}$ MLVSS concentration.

Synthetic wastewater was prepared to feed the reactors which composed macro and micronutrients that was described at Egli et al. [14] and contains 1:1.1 ratio ammonium to nitrite, as $100 \mathrm{mg} \mathrm{L}^{-1} \mathrm{NH}_{4}-\mathrm{N}$ and $110 \mathrm{mg} \mathrm{L}^{-1} \mathrm{NO}_{2}-\mathrm{N}$ for batch studies and for continuous rector $300 \mathrm{mg} \mathrm{L}^{-1}$ $\mathrm{NH}_{4}-\mathrm{N}$ and $330 \mathrm{mg} \mathrm{L}^{-1} \mathrm{NO}_{2}-\mathrm{N}$. Besides, nitrate was added as a concentration of $50 \mathrm{mg} \mathrm{L}^{-1} \mathrm{NO}_{3}-\mathrm{N}$ in order to ensure anoxic condition and to avoid decaying of Anammox biomass.

\subsection{Experimental Setup Long-Term Experiment}

For long-term experiments, a plexiglass continuous flow up-flow reactor was designed which has an active volume of $2.31 \mathrm{~L}$ with diameter $7 \mathrm{~cm}$ and height of $60 \mathrm{~cm}$. The average flowrate of the system was $1800 \mathrm{~mL} \mathrm{~d}^{-1}$ and hydraulic retention time was $1.28 \mathrm{~d}$. The reactor was half full filled up with Type K1 Kaldnes rings packing material to provide abundant biomass retention. The carrier materials were provided by Anox Kaldnes Company and made of polyethylene (PEHD) material with nominal length and diameter $7.2 \mathrm{~mm}$ and $9.1 \mathrm{~mm}$, respectively. The reactor was operated under $35 \pm 1{ }^{\circ} \mathrm{C}$ to provide constant temperature water bath was used around the reactor. To enable the anoxic conditions inside the reactor $90 \% \mathrm{~N}_{2}+10 \% \mathrm{CO}_{2}$ gas combination was supplied from the bottom of the column. By this way, required inorganic carbon source was supplied by $\mathrm{CO}_{2}$ that is found in the gas mixture.

\subsection{Batch Studies}

In order to determine the effect of short-term exposure of $\mathrm{Cu}(\mathrm{II})$ batch tests were carried out in side armed glass reactors with $100 \mathrm{~mL}$ total volume and $50 \mathrm{~mL}$ liquid phase volume. $100 \mathrm{mg} / \mathrm{L}$ $\mathrm{NH}_{4}-\mathrm{N}$ and $110 \mathrm{mg} / \mathrm{L} \mathrm{NO}_{2}-\mathrm{N}$ were added to the mineral medium. To provide seed sludge for batch experiments, Anammox biomass was enriched in a sequencing batch reactor (SBR) operated at a sludge retention time of 50 days. After steady-state conditions and $90 \%$, nitrogen removal efficiencies were achieved in the SBR, mixed liquor was taken from the reactor for batch inhibition studies. The reactors were inoculated with Anammox biomass approximately as $800 \pm 100 \mathrm{mg} \mathrm{L}^{-1}$ MLVSS concentration. The anoxic condition was provided by purging nitrogen gas inside the 
reactors. The reactors were incubated at $35 \pm 1{ }^{\circ} \mathrm{C}$ and $150 \mathrm{rpm}$. Batch system configuration is shown in Figure 1. Samples were obtained every $3 \mathrm{~h}$ and analyzed for ammonium and nitrite nitrogen during the $24-\mathrm{h}$ period.

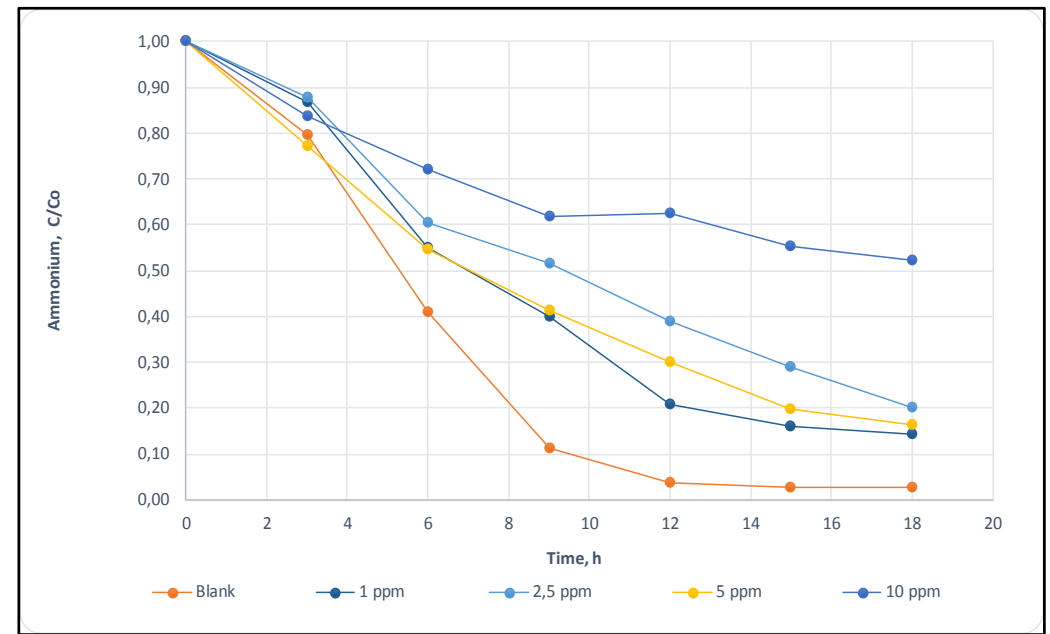

(a)

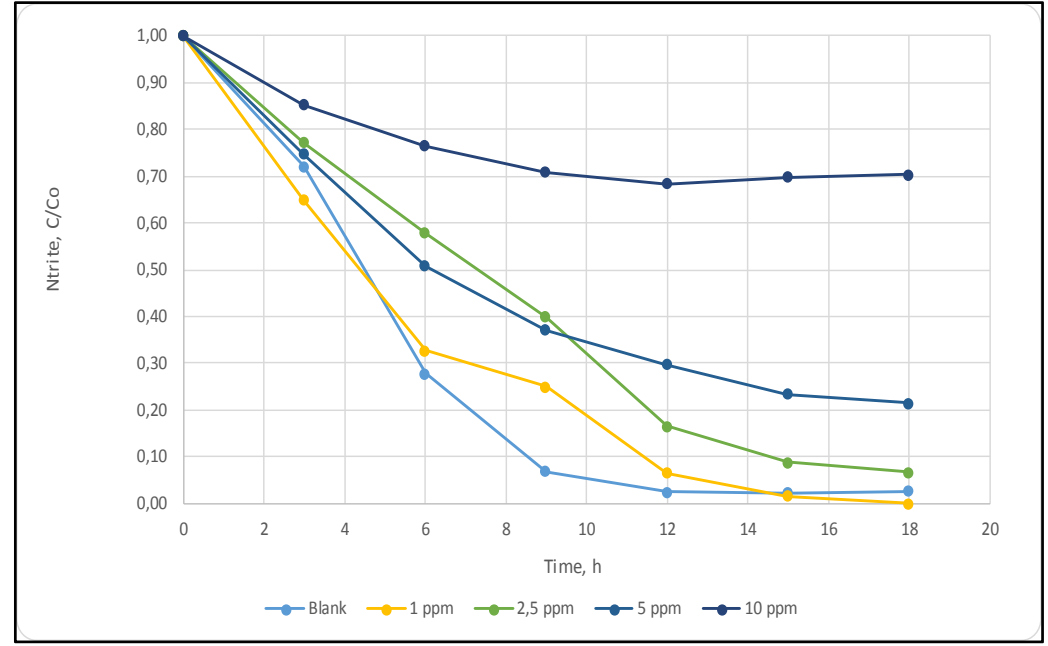

(b)

Figure 1. (a) The effect of $\mathrm{Cu}$ on the removal efficiency of ammonium-nitrogen. (b) The effect of $\mathrm{Cu}$ on the removal efficiency of nitrite-nitrogen

\subsection{Analytical Methods}

High-Pressure Liquid Chromatography (HPLC) was used to determine nitrite and nitrate concentrations. The ammonium concentrations were measured by using Nesslerization method. Volatile suspended solids (VSS) and suspended solids(SS) measurements were done by using gravimetric methods according to standard methods [35].

$\mathrm{Cu}$ concentrations were measured using Perkin Elmer Analyst 400 Flame Atomic Absorption Spectrometry (AAS). In batch tests, copper concentrations were measured after $24 \mathrm{~h}$ exposure time.

\subsection{Evaluation of IC50 Values}

In order to calculate median inhibition concentration (IC50), both linear and nonlinear regression models were applied using GraphPad Prism 7 software. IC50 values were calculated based on total nitrogen (ammonium nitrogen + nitrite nitrogen) oxidation rate and modified non-competitive inhibition model was chosen.

- $\quad$ Modified non-competitive inhibition model 


$$
I \%=100 \times\left(1-\frac{1}{1+\left(\frac{H M}{a}\right)^{b}}\right)
$$

where $I \%$ is the inhibition response, a is the concentration causing $50 \%$ inhibition in nitrogen removal rate., $\mathrm{b}$ is a fitting parameter,

NRR was calculated based on the fast initial rate and was calculated by using Equation (2).

$$
N R R\left(\frac{\frac{m g N}{m g V S S}}{h}\right)=\frac{\left(T N_{(\mathrm{inf})}-T N_{(e f f)}\right)}{t \times V S S}
$$

where $T N_{(i n f)}$ and $T N_{(e f f)}$ were initial and final total nitrogen concentrations. Percent inhibition values were calculated according to Equation (3).

$$
\% \text { inhibition }=100-\left(\frac{N R R_{w / H M} \times 100}{N R R_{\text {blank }}}\right)
$$

\section{Results and Discussion}

\subsection{Short-Term Effect of $\mathrm{Cu}$ on Anammox}

In order to evaluate the IC50 levels and nitrogen removal rates (NRR) for short-term responses, batch tests were performed by using increasing level of heavy metal concentrations. To monitor the ammonia nitrogen and nitrite nitrogen removal rates samples were taken every three hours and analyzed during the 24-h time period. Four different $\mathrm{Cu}$ metal concentration ( $1 \mathrm{ppm}, 2.5 \mathrm{ppm}, 5 \mathrm{ppm}$ and $10 \mathrm{ppm}$ ) were tested to determine the level of inhibition and the effect of metal concentration on ammonia and nitrite nitrogen removal were shown in Figure 1.

To analyze inhibition level of heavy metal on Anammox bacteria various inhibition models were studied as non-competitive inhibition model, modified non-competitive inhibition model, linear model and 4-point logistic method (Figure 2). The consistency of the inhibition model to the experimental data was fitted with minimum squared errors method and it was found that modified non-competitive is the most representative model. Also, some researchers used the modified non-competitive model to express the heavy metal inhibition on the biochemical process $[27,34,36,37]$. Therefore, IC50 values for short-term inhibition was determined by modified non-competitive inhibition model.

IC50 levels for short-term exposure calculated as $4.57 \mathrm{mg} \mathrm{L}^{-1}\left(\mathrm{R}^{2}: 0.97\right.$ according to $95 \%$ confidence interval) from the modified non-competitive inhibition model based on total applied $\mathrm{Cu}$ concentration. The removal rate was calculated as $37 \mathrm{mg} \mathrm{TN} / \mathrm{mgVSS} / \mathrm{h}$ for the control samples, however, NRR was reduced to $11 \mathrm{mg} \mathrm{Nmg}^{-1} \mathrm{VSSh}^{-1}$ for the $10 \mathrm{ppm} \mathrm{Cu}$ added samples. Figure 3 illustrates the decrease on the NRR with increasing $\mathrm{Cu}$ concentrations.

Pertinent literature concerning the inhibitory effect of $\mathrm{Cu}$ reveals the toxic effect of $\mathrm{Cu}$ on Anammox process. Lotti et al. [33] reported the heavy metal concentration which causes the $50 \%$ decrease in Anammox activity(IC50) as $1.9 \mathrm{mg} \mathrm{L}^{-1}$, on the other hand Zhang et al. reported that the short-term inhibition IC50 level as $32.5 \mathrm{mg} \mathrm{L}^{-1}$ and Van del Rio et al. [38] found for the same level of inhibition concentration as $19.3 \mathrm{mg} \mathrm{L}^{-1}$. The variability of the results may be explained by the different Anammox species that take arole in the conversions. Therefore, Anammox species that exposed the heavy metals should be also determined for further analysis. 


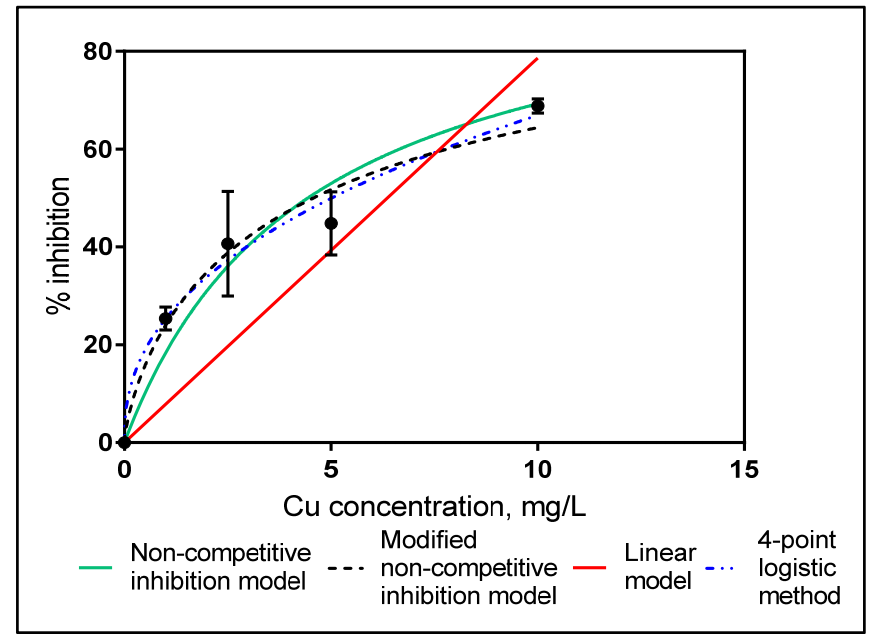

Figure 2. Relative percent inhibition vs. Cu Concentrations (Applied inhibition models).

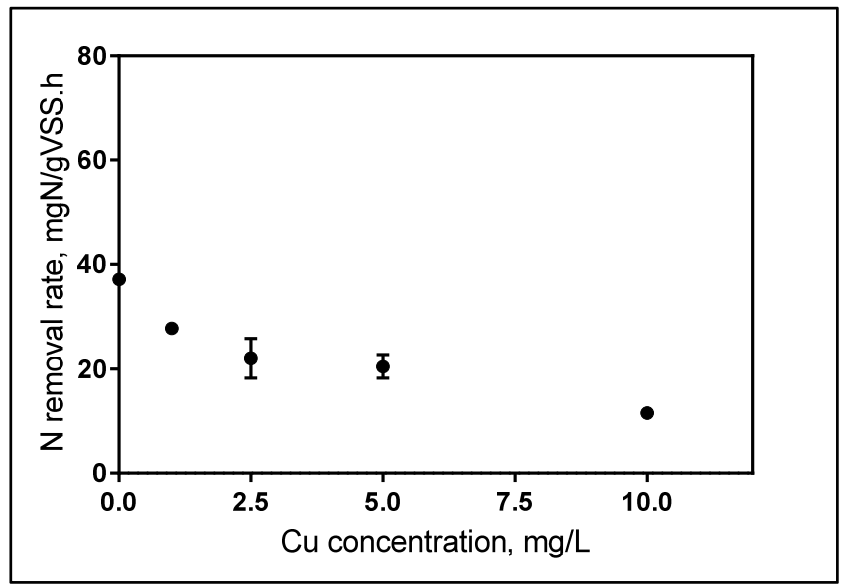

Figure 3. The inhibitory effect of $\mathrm{Cu}$ on nitrogen removal rate.

\subsection{Long-Term Effect of $\mathrm{Cu}$ on Anammox}

Prior the heavy metal exposure, continuous flow system was operated approximately one year and enrichment of the reactor was achieved with $94 \%$ nitrogen removal efficiency. Afterward, in order to test the long-term inhibitory effect of $\mathrm{Cu}$ on the reactor performance, the system operated for 240 days under gradually increased $\mathrm{Cu}$ loadings (Figure 4). Heavy metal concentration was increased stepwise from $0.2 \mathrm{mg} \mathrm{L}^{-1}$ to $8 \mathrm{mg} \mathrm{L}^{-1}$ and the average removal rate of nitrogen was found at $97 \%$ to $6 \mathrm{ppm} \mathrm{Cu}$ addition. The enhancement effect of $\mathrm{Cu}$ addition at low concentrations has been reported by many researchers [27,39]. In literature, the presence of some heavy metals at low concentrations play a crucial role to stimulate metabolism of microorganisms. $\mathrm{Cu}$ is one of the essential micronutrients for many enzymes of microorganisms. Chen et al. [39] reported that $\mathrm{Cu}$ concentration should be kept below $4 \mathrm{mg} \mathrm{L}^{-1}$ to provide good reactor capacity and the optimum dosage to improve the specific anammox activity indicated as $1.18 \mathrm{mg} \mathrm{L}^{-1}$. In our study, we observed the enhancement of the nitrogen removal rate until $\mathrm{Cu}$ concentration reached up to $6 \mathrm{ppm}$. As it was shown in Figure 5 the removal efficiency started to decrease after 180 days at 6 ppm Cu addition.

The nitrogen removal rate between $0.2 \mathrm{mg} \mathrm{L}^{-1}$ to $6 \mathrm{mg} \mathrm{L}^{-1}$ was calculated as $19.10 \pm 0.60 \mathrm{mg} \mathrm{NL}^{-1}$ $\mathrm{h}^{-1}$ (according to $95 \%$ confidence interval) and after that point removal rates started to decrease. Figure $5 \mathrm{~b}$ shows the nitrogen removal rates under stepwise increase of $\mathrm{Cu}$ concentrations. The nitrogen removal rates decreased to $2.2 \mathrm{mg} \mathrm{NL}^{-1} \mathrm{~h}^{-1}$ when $\mathrm{Cu}$ concentration reached up to $8 \mathrm{ppm}$.

To identify the IC50 levels for the long-term exposure of $\mathrm{Cu}$ the experimental data were fitted with the modified non-competitive inhibition model and calculated as $6.77 \mathrm{mg} \mathrm{L}^{-1}$ ( $\mathrm{R}^{2}: 0.95$ according to $95 \%$ confidence interval) based on removal efficiency of nitrogen. Figure 5 a shows the applied $\mathrm{Cu}$ 
concentration versus the percent inhibition values according to modified non-competitive inhibition model.

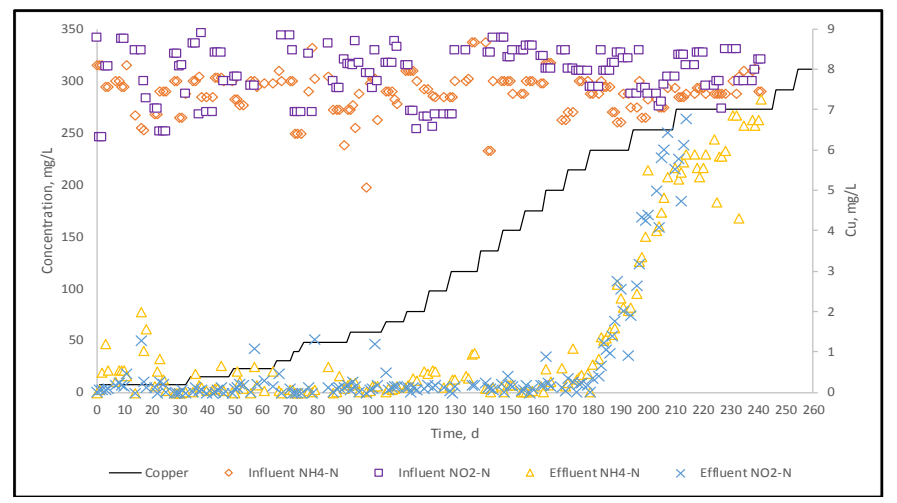

Figure 4. Influent and effluent ammonia and nitrite nitrogen profiles during $\mathrm{Cu}$ exposure.

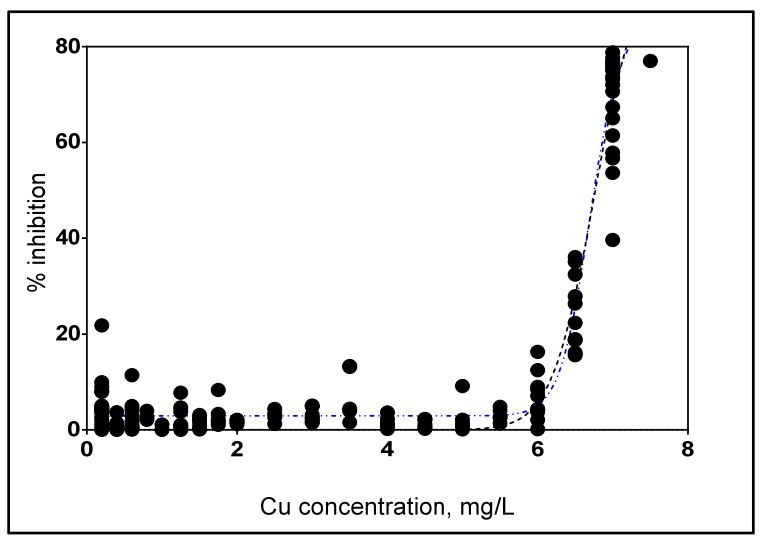

(a)

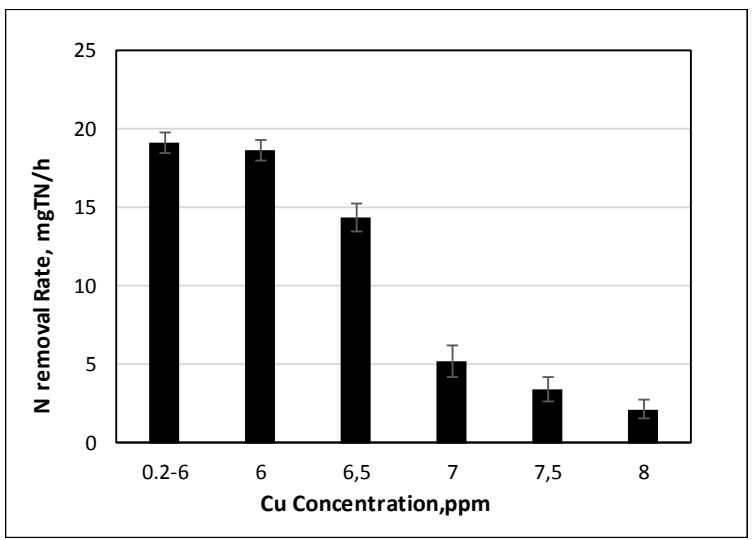

(b)

Figure 5. (a) Relative Percent inhibition vs. Cu concentration (b) Nitrogen removal rates during long-term exposure.

Yang et al. [26] reported that theIC50 value as $12.9 \mathrm{mg} \mathrm{L}^{-1}$ for the short-term inhibition, while they investigated the long-term inhibition in upflow anaerobic sludge blanket reactor and found $94 \%$ activity loss when $5 \mathrm{mg} \mathrm{L}^{-1} \mathrm{Cu}$ added to the system. Zhang et al. [40] also report $65 \%$ reduction in NRR when $\mathrm{Cu}$ concentration was increased 5 to $8 \mathrm{mg} \mathrm{L}^{-1}$. For both of the studies, they observed higher tolerance to $\mathrm{Cu}$ in short-term exposures rather than long-term. In contrast to earlier findings, we have obtained higher median inhibition levels in long-term exposure. The possible reason for that starting from very low concentrations of $\mathrm{Cu}$ in our study may have provided suitable conditions for adaptation of the microorganisms.

\section{Conclusions}

Results have shown that the IC50 level on Anammox of short-term Cu effect was $4.57 \mathrm{mg} \mathrm{L}^{-1}$ while in long-term exposure the value increased to $6.77 \mathrm{mg} \mathrm{L}^{-1}$. This difference can be attributed to the self-adaptation of Anammox bacteria in the continuous flow reactor in a time period of 240 days.

Author Contributions: C.K.A. is the corresponding author of the paper. She is responsible from the experimental setup, AAS measurements, and evaluation of the IC50 values by using GraphPad Prism program. A.E.U. is a master student she was responsible from some analytical measurements like ammonium, volatile suspended solid, suspended solids and HPLC measurements. K.Y. is the advisor of this study and B.M. is the co-advisor. They are responsible from the examination and interpretation of the results.

Funding: Marmara University Scientific Research Committee-BAPKO (Project No. FEN-A-111017-0583). 
Acknowledgments: The financial support of this study by Marmara University Scientific Research Committee-BAPKO (Project No. FEN-A-111017-0583) is gratefully acknowledged.

Conflicts of Interest: We wish to confirm that there are no known conflicts of interest associated with this publication and there has been no significant financial support for this work that could have influenced its outcome.

\section{References}

1. Larsdotter, K. Wastewater treatment with microalgae-A literature review. Vatten 2006, 62, 31-38.

2. Zhu, G.; Peng, Y.; Li, B.; Guo, J.; Yang, Q.; Wang, S. Biological removal of nitrogen from wastewater. Rev. Environ. Contam. Toxicol. 2008, 192, 159-195. doi:10.1007/978-0-387-71724-1_5.

3. Schmidt, I.; Sliekers, O.; Schmid, M.; Bock, E.; Fuerst, J.; Kuenen, J.G.; Jetten, M.S.M.; Strous, M. New concepts of microbial treatment processes for the nitrogen removal in wastewater. FEMS Microbiol. Rev. 2003, 27, 481-492. doi:10.1016/S0168-6445(03)00039-1.

4. Van der Star, W.R.L.; Abma, W.R.; Blommers, D.; Mulder, J.W.; Tokutomi, T.; Strous, M.; Picioreanu, C.; van Loosdrecht, M.C.M. Startup of reactors for anoxic ammonium oxidation: Experiences from the first full-scale anammox reactor in Rotterdam. Water Res. 2007, 41, 4149-4163. doi:10.1016/j.watres.2007.03.044.

5. Kartal, B.; Kuenen, J.G.; Van Loosdrecht, M.C.M. Sewage treatment with anammox. Science 2010, 328, 702-703. doi:10.1126/science.1185941.

6. Jetten, M.S.M.; Strous, M.; Van De Pas-Schoonen, K.T.; Schalk, J.; Van Dongen, U.G.J.M.; Van De Graaf, A.A.; Logemann, S.; Muyzer, G.; Van Loosdrecht, M.C.M.; Kuenen, J.G. The anaerobic oxidation of ammonium. FEMS Microbiol. Rev. 1998, 22, 421-437. doi:10.1016/S0168-6445(98)00023-0.

7. Strous, M.; Kuenen, J.G.; Fuerst, J.A.; Wagner, M.; Jetten, M.S.M. The anammox case-A new experimental manifesto for microbiological eco-physiology, Antonie van Leeuwenhoek. Int. J. Gen. Mol. Microbiol. 2002, 81, 693-702. doi:10.1023/A:1020590413079.

8. Imajo, U.; Tokutomi, T.; Furukawa, K. Granulation of Anammox microorganisms in up-flow reactors. Water Sci. Technol. 2004, 49, 155-163.

9. Isaka, K.; Date, Y.; Sumino, T.; Tsuneda, S. Ammonium removal performance of anaerobic ammoniumoxidizing bacteria immobilized in polyethylene glycol gel carrier: Anammox bacteria immobilized in gel carrier. Appl. Microbiol. Biotechnol. 2007, 76, 1457-1465. doi:10.1007/s00253-007-1106-6.

10. Szatkowska, B.; Cema, G.; Plaza, E.; Trela, J.; Hultman, B. A one-stage system with partial nitritation and Anammox processes in the moving-bed biofilm reactor. Water Sci. Technol. 2007, 55, 19-26. doi:10.2166/wst.2007.237.

11. Aktan, C.K.; Yapsakli, K.; Mertoglu, B. Inhibitory effects of free ammonia on Anammox bacteria. Biodegradation 2012, 23, 751-762. doi:10.1007/s10532-012-9550-0.

12. Strous, M.; Van Gerven, E.; Kuenen, J.G.; Jetten, M. Effects of aerobic and microaerobic conditions on anaerobic ammonium-oxidizing (Anammox) sludge. Appl. Environ. Microbiol. 1997, 63, 2446-2448.

13. Akgul, D.; Aktan, C.K.; Yapsakli, K.; Mertoglu, B. Treatment of landfill leachate using UASB-MBRSHARON-Anammox configuration. Biodegradation 2013, 24, 399-412. doi:10.1007/ s10532-012-9597-y.

14. Egli, K.; Fanger, U.; Alvarez, P.J.J.; Siegrist, H.; Van der Meer, J.R.; Zehnder, A.J.B. Enrichment and characterization of an anammox bacterium from a rotating biological contactor treating ammonium-rich leachate. Arch. Microbiol. 2001, 175, 198-207. doi:10.1007/s002030100255.

15. Furukawa, K.; Inatomi, Y.; Qiao, S.; Quan, L.; Yamamoto, T.; Isaka, K.; Sumino, T. Innovative treatment system for digester liquor using anammox process. Bioresour. Technol. 2009, 100, 5437-5443. doi:10.1016/j.biortech.2008.11.055.

16. Dapena-Mora, A.; Campos, J.L.; Mosquera-Corral, A.; Méndez, R. Anammox process for nitrogen removal from anaerobically digested fish canning effluents. Water Sci. Technol. 2006, 53, 265-274. doi:10.2166/wst.2006.429.

17. Tokutomi, T.; Yamauchi, H.; Nishimura, S.; Yoda, M.; Abma, W. Application of the Nitritation and Anammox Process into Inorganic Nitrogenous Wastewater from Semiconductor Factory. J. Environ. Eng. 2011, 137, 146-154. doi:10.1061/(ASCE)EE.1943-7870.0000303.

18. Fux, C.; Marchesi, V.; Brunner, I.; Siegrist, H. Anaerobic ammonium oxidation of ammonium-rich waste streams in fixed-bed reactors. Water Sci. Technol. 2004, 49, 77-82.

19. Jin, R.C.; Yang, G.F.; Yu, J.J.; Zheng, P. The inhibition of the Anammox process: A review. Chem. Eng. J. 2012, 197, 67-79. doi:10.1016/j.cej.2012.05.014. 
20. Tang, C.J.; Zheng, P.; Zhang, L.; Chen, J.W.; Mahmood, Q.; Chen, X.G.; Hu, B.L.; Wang, C.H.; Yu, Y. Enrichment features of anammox consortia from methanogenic granules loaded with high organic and methanol contents. Chemosphere 2010, 79, 613-619. doi:10.1016/j.chemosphere.2010.02.045.

21. Dapena-Mora, A.; Fernández, I.; Campos, J.L.; Mosquera-Corral, A.; Méndez, R.; Jetten, M.S.M. Evaluation of activity and inhibition effects on Anammox process by batch tests based on the nitrogen gas production. Enzyme Microb. Technol. 2007, 40, 859-865. doi:10.1016/j.enzmictec.2006.06.018.

22. Waki, M.; Tokutomi, T.; Yokoyama, H.; Tanaka, Y. Nitrogen removal from animal waste treatment water by anammox enrichment. Bioresour. Technol. 2007, 98, 2775-2780. doi:10.1016/j.biortech.2006.09.031.

23. Fernández, I.; Vázquez-Padín, J.R.; Mosquera-Corral, A.; Campos, J.L.; Méndez, R. Biofilm and granular systems to improve Anammox biomass retention. Biochem. Eng. J. 2008, 42, 308-313. doi:10.1016/ j.bej.2008.07.011.

24. Li, G.; Puyol, D.; Carvajal-Arroyo, J.M.; Sierra-Alvarez, R.; Field, J.A. Inhibition of anaerobic ammonium oxidation by heavy metals. J. Chem. Technol. Biotechnol. 2015, 90, 830-837. doi:10.1002/jctb.4377.

25. Daverey, A.; Chen, Y.C.; Sung, S.; Lin, J.G. Effect of zinc on anammox activity and performance of simultaneous partial nitrification, anammox and denitrification (SNAD) process. Bioresour. Technol. 2014, 165, 105-110. doi:10.1016/j.biortech.2014.04.034.

26. Yang, G.F.; Ni, W.M.; Wu, K.; Wang, H.; Yang, B.E.; Jia, X.Y.; Jin, R.C. The effect of Cu(II) stress on the activity, performance and recovery on the Anaerobic Ammonium-Oxidizing (Anammox) process. Chem. Eng. J. 2013, 226, 39-45. doi:10.1016/j.cej.2013.04.019.

27. Zhang, Z.Z.; Zhang, Q.Q.; Xu, J.J.; Deng, R.; Ji, Z.Q.; Wu, Y.H.; Jin, R.C. Evaluation of the inhibitory effects of heavy metals on anammox activity: A batch test study. Bioresour. Technol. 2016, 200, 208-216. doi:10.1016/j.biortech.2015.10.035.

28. Zhang, Z.Z.; Deng, R.; Cheng, Y.F.; Zhou, Y.H.; Buayi, X.; Zhang, X.; Wang, H.Z.; Jin, R.C. Behavior and fate of copper ions in an anammox granular sludge reactor and strategies for remediation. J. Hazard. Mater. 2015, 300, 838-846. doi:10.1016/j.jhazmat.2015.08.024.

29. Kjeldsen, P.; Barlaz, M.A.; Rooker, A.P.; Baun, A.; Ledin, A.; Christensen, T.H. Present and long-term composition of MSW landfill leachate: A review. Crit. Rev. Environ. Sci. Technol. 2002, 32, $297-336$. doi:10.1080/10643380290813462.

30. Kimura, Y.; Isaka, K. Evaluation of inhibitory effects of heavy metals on anaerobic ammonium oxidation (Anammox) by continuous feeding tests. Appl. Microbiol. Biotechnol. 2014, 98, 6965-6972. doi:10.1007/s00253-014-5735-2.

31. Li, G.; Puyol, D.; Field, J.A. Inhibitory effect of heavy metals on nitrogen production by anaerobic ammonium oxidation bacteria. In Proceedings of the 13th World Congress on Anaerobic Digestion, Santiago de Compostela, Spain, 25-28 June 2013.

32. Zhang, Z.Z.; Zhang, Q.Q.; Xu, J.J.; Shi, Z.J.; Guo, Q.; Jiang, X.Y.; Wang, H.Z.; Chen, G.H.; Jin, R.C. Long-term effects of heavy metals and antibiotics on granule-based anammox process: Granule property and performance evolution. Appl. Microbiol. Biotechnol. 2016, 100, 2417-2427. doi:10.1007/s00253-015-7120-1.

33. Lotti, T.; Cordola, M.; Kleerebezem, R.; Caffaz, S.; Lubello, C.; Van Loosdrecht, M.C.M. Inhibition effect of swine wastewater heavy metals and antibiotics on anammox activity. Water Sci. Technol. 2012, 66, 1519-1526. doi:10.2166/wst.2012.344.

34. Bi, Z.; Qiao, S.; Zhou, J.; Tang, X.; Cheng, Y. Inhibition and recovery of Anammox biomass subjected to short-term exposure of $\mathrm{Cd}, \mathrm{Ag}$, Hg and Pb. Chem. Eng. J. 2014, 244, 89-96. doi:10.1016/j.cej.2014.01.062.

35. American Public Health Association (APHA); American Water Works Association (AWWA); World Economic Forum (WEF). Standard Methods for the Examination of Water and Wastewater; American Public Health Association: Washington, DC, USA, 2005; pp. 1-2671.

36. Liang, Z.; Liu, J.X.; Li, J. Decomposition and mineralization of aquatic humic substances (AHS) in treating landfill leachate using the Anammox process. Chemosphere 2009, 74, 1315-1320. doi:10.1016/ j.chemosphere.2008.11.073.

37. Hu, Z.; Chandran, K.; Grasso, D.; Smets, B.F. Effect of nickel and cadmium speciation on nitrification inhibition. Environ. Sci. Technol. 2002, 36, 3074-3078. doi:10.1021/es015784a.

38. Val del Río, Á.; da Silva, T.; Martins, T.; Foresti, E.; Campos, J.L.; Méndez, R.; Mosquera-Corral, A. Partial Nitritation-Anammox Granules: Short-Term Inhibitory Effects of Seven Metals on Anammox Activity. Water Air Soil Pollut. 2017, 228, 439. doi:10.1007/s11270-017-3628-6. 
39. Chen, H.; Yu, J.J.; Jia, X.Y.; Jin, R.C. Enhancement of anammox performance by Cu(II), Ni(II) and Fe(III) supplementation. Chemosphere 2014, 117, 610-616. doi:10.1016/j.chemosphere.2014.09.047.

40. Zhang, Q.Q.; Zhang, Z.Z.; Guo, Q.; Chen, Q.Q.; Jin, R.C.; Jia, X.Y. Variation in the performance and sludge characteristics of anaerobic ammonium oxidation inhibited by copper. Sep. Purif. Technol. 2015, 142, 108-115. doi:10.1016/j.seppur.2014.11.048.

(C) 2018 by the authors. Licensee MDPI, Basel, Switzerland. This article is an open access article distributed under the terms and conditions of the Creative Commons Attribution (CC BY) license (http://creativecommons.org/licenses/by/4.0/). 